\title{
Gonadal Development of Peprilus medius (Peters, 1869) (Perciformes: Stromateidae) from Southeast of the Gulf of California, Mexico
}

\author{
Desarrollo Gonádico de Peprilus medius (Peters, 1869) (Perciformes: Stromateidae) \\ del Sureste del Golfo de California, México
}

\begin{abstract}
Maria de los Angeles Maldonado-Amparo ${ }^{1,3}$;Rebeca Sánchez-Cárdenas²; Luis Antonio Salcido-Guevara ${ }^{3}$ \& Jorge Saúl Ramírez-Pérez ${ }^{1}$
\end{abstract}

MALDONADO-AMPARO, M. A.; SÁNCHEZ-CÁRDENAS, R.; SALCIDO-GUEVARA, L.A. \& RAMÍREZ-PÉREZ, J. S. Gonadal development of Peprilus medius (Peters, 1869) (Perciformes: Stromateidae) from southeast of the Gulf of California, Mexico. Int. J. Morphol., 35(1):56-61, 2017.

SUMMARY: The gonadal development assessment is a fundamental work in researching the reproduction of Peprilus medius, on the way to understand its population dynamics and to achieve a sustainable management of its fisheries. The diagnosis based on morphochromatic features is the quicker, more practical and cheaper method, and properly validated, it may be an accurate procedure. This is particularly useful in researches when it is required to provide prompt and accurate information to support decision-making for fisheries management, and during long-term fisheries monitoring to detect changes in reproductive patterns due to environmental anomalies. These are issues of concern in $P$. medius and other fishery resources. In this context, a scale that describes the gonadal development through morphochromatic and histological features is presented, and plus anatomical observations of the reproductive organs. Ovarian development was characterized through six phases: immature, development (sub-phases: early and late), mature, spawning (sub-phases: partial and partial post-spawning), post-spawning and resting. Testicular development was described through five phases: immature, development, ejaculation, ejaculated and resting. The position and shape of the reproductive organs are apparently defined by the shape of the fish and the visceral cavity. P. medius's gonads show a gonadal lobe at lower position and an upper lobe in the visceral cavity, and both lobes presented a horizontal placement from gonopore toward the back of the fish. In addition, gonadal deformities occurrence due to deformities in the visceral cavity was evidenced. We recommend to use presented descriptions as a guide in gonadal assessment.

KEY WORDS: Ovaries; Testes; Gametogenesis; Reproductive anatomy.

\section{INTRODUCTION}

Peprilus medius (Peters, 1869) is a fish of Stromateidae family that inhabits in the neritic-pelagic zone from the Gulf of California to northern of Chile, and Galapagos Islands (Chirichigno \& Velez, 1998; Tobón-López et al., 2008; Palacios-Salgado et al., 2012). Accurate knowledge about morphology and development of reproductive organs of $P$. medius has not been published, but there is some information about other stromatids. Such as, Peprilus triacanthus's ovaries were described as symmetric and paralleled organs, fused at the posterior portion, having triangular-circular cross-sectional form and localized completely in the visceral cavity (Kobelkowsky, 2012). The ovaries of Pampus argenteus and
Stromateus stellatus present an asynchronous development, which is consistent with partial spawning mode (Dadzie et al., 2000; Almatar et al., 2004; Lone et al., 2008; Carocca \& Chong, 2010). The development of ovaries of Peprilus burti was briefly described by eight morphochromatic phases: immature, maturing virgin, early developing/resting, late developing I, late developing II, gravid, ripe and spawning/ spent (Murphy \& Chittenden, 1991). Latter, Pampus argenteus's ovaries development was described by seven morphochromatic phases: virgin, developing, maduring, ripening, spawning or running, partially spawned, spend and resting (Almatar et al.; Lone et al.).

\footnotetext{
${ }^{1}$ Facultad de Ciencias del Mar, Universidad Autónoma de Sinaloa. Paseo Claussen s/n, Col. Los Pinos, C.P. 82000, Mazatlán, Sinaloa, México. ${ }^{2}$ CONACyT - FACIMAR, UAS, México.

${ }^{3}$ Master student.
} 
P. medius is socially and economically important in several coastal communities along its geographic distribution, because it is a target species in the coastal fishery for human consumption, to make fish meal and to use it as bait (Inga-Barreto et al., 2008; Prado, 2010). As with many other species, there is a growing concern to study and to monitor systematically its populations to get biological information to make fishery decisions. Particularly, because $P$. medius could change its reproductive behavior due to strong environmental changes (Kameya et al., 2001; King \& McFarlane, 2003 \& Tam et al., 2008). In this context, this contribution describes phases of gonadal development of $P$. medius defined by morphochromatic and histological traits, and some additional anatomical findings, as a guideline for accurate identifying gonad maturation status in an easy, cheap and quick manner. This is particularly useful for extensive fishery monitoring.

\section{MATERIAL AND METHOD}

A weekly sampling of ten $P$. medius specimens was made through artisanal fishery from Mazatlan, Mexico, during September 2014 to November 2015. Fishes were weighed (Wt) and dissected to observe and remove the reproductive organs. Each gonad was photographed and its size, texture, weight ( $\mathrm{Wg}$ ), color, form and position in visceral cavity were registered. Gonadosomatic index (GSI) was calculated as $\mathrm{Wg} /(\mathrm{Wt}-\mathrm{Wg})$ and expressed as a percentage (Devlaming et al., 1982). The RGB color values were defined using color tool of Paint application (Windows 2010 version) from photographs of gonads and making manual adjustments.

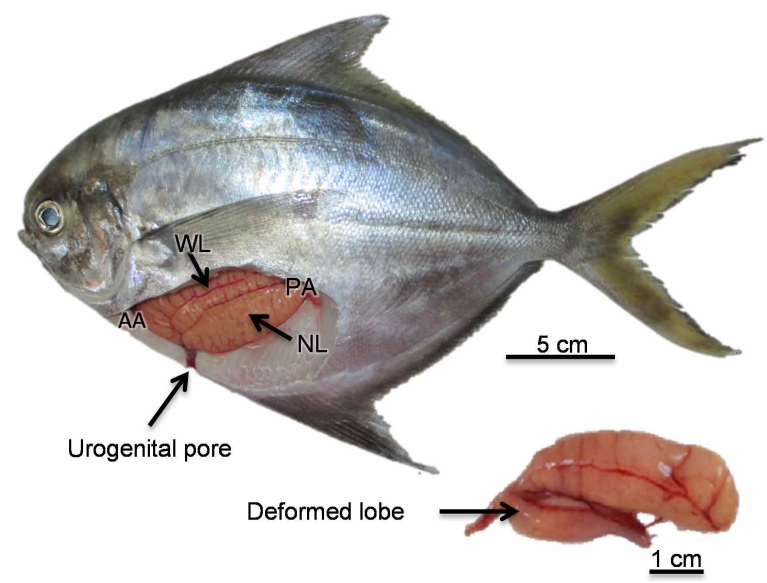

Fig. 1. Gonads position in Peprilus medius and a deformed ovary. AA, anterior area; WL, wider lobe; NL, narrower lobe; PA, posterior area.
Gonads were fixed in $10 \%$ formalin, and then crosssectional sections were dehydrated, cleared and paraffinembedded, and $5 \mathrm{~mm}$-thick sections were obtained and stained through hematoxylin-eosin technique, using dewaxing with soap (Humason, 1979; Buesa \& Peshkov, 2009).

Gonads phases firstly were described according with their morphochromatic features (including average RGB color values) and GSI, followed by the histological diagnosis. The gonadal phase was determined based on gametes stages (types, organization and more advanced stage of gamete), structure of wall and gonadal stroma, and the presence of elements as post-ovulatory follicles and atresia, following Wallace \& Selman (1981), Lone et al., and Núñez $\&$ Duponchelle (2008).

\section{RESULTS}

The ovaries and testes of $P$. medius are formed by two elongated lobes, and usually one lobe is wider, being most evident when the organ is mature. The gonad is contained and has to develop in a cavity with a horizontal narrow space and a larger vertical space. The cavity wall is not flexible and the gonopore is approximately under the middle cavity space. The gonadal lobes are horizontally positioned since the gonopore (gonoduct connection) to posterior area of visceral cavity, and the narrower lobe is lying on the ventral side (lower lobe) of the cavity and the wider is up (upper lobe) (Fig. 1). The gonads may present the lower lobe deformed (very small) due to a cavity deformity (Fig. 1).

Six ovarian development phases were described: immature, development, mature, spawning, post-spawning and resting (Table I; Fig. 2). During ovarian development and subsequent phases more than two oocytes stages were observed simultaneously. The oocyte release was in batches following two patterns: frequently it is a continuous release (just released a batch is preparing to release the next, and it was called partial spawning); but a few times (34.8\%) is a release with pauses (post-ovulatory follicles are almost reabsorbed and the next batch is in diapause, and it was called partial post-spawning). These spawning patterns were observed only by histological diagnosis, and also the difference between immature and resting phases.

Five testicular development phases were described: immature, development, ejaculation, ejaculated and resting (Table II; Fig. 3). The testes presented continuous spermatogenesis and simultaneous spermatozoa release during ejaculation phase, and near the end of spawning, the spermatogenesis was gradually reduced. 
MALDONADO-AMPARO, M. A.; SÁNCHEZ-CÁRDENAS, R.; SALCIDO-GUEVARA, L.A. \& RAMÍREZ-PÉREZ, J. S. Gonadal development of Peprilus medius (Peters, 1869) (Perciformes: Stromateidae) from southeast of the Gulf of California, Mexico. Int. J. Morphol., 35(1):56-61, 2017.

Table I. Scale of ovarian developmental phases of Peprilus medius from southeast of Gulf of California.

\begin{abstract}
Phase Microscopic features

Immature. Only oocytes in primary growth stages are present: nuclear chromatin $(23.73 \pm 3.5 \mu \mathrm{m}$ in diameter $)$ and perinucleolar $(32.59 \pm 0.67 \mu \mathrm{m}$ in diameter). The ovary wall and lamellae's connective tissue are thin with respect to ovary in resting phase. The ovarian stroma appearance is compact and organized. Fig. 2 A.

Development

Early developing. The cortical alveolus $(59.54 \pm 1.36 \mu \mathrm{m}$ in diameter) is the more advanced stage of oocytes in the ovary. Primary growth oocytes are still present. Fig. 2 B.
\end{abstract}

Late developing. $\mathrm{O}$ ocytes in vitellogenesis stages are predominant: early vitellogenesis $(\mathrm{Vt} 1,126.60 \pm 4.52 \mu \mathrm{m}$ in diameter) and late vitellogenesis ( Vt2, 162.27 $\pm 3.02 \mu \mathrm{m}$ in diameter). Vt1 oocytes are scarcer than Vt2. Primary growth oocytes are still present. Fig. 2 C.

Mature. Oocytes in migratin[ -nucleus stage $(195.22 \pm 1.88 \mu \mathrm{m}$ in diameter) are present (final maturation). All earliest oocytes stages can be observed in the ovarian stroma. Oocytes in primary growth are less evident. Fig. $2 \mathrm{D}$.

\section{Spawning}

Partial spawning. Post-ovulatory follicles and oocytes in different stages of development (at least three) are present. Some atretic oocytes can be observed due to follicular atresia process. One batch of oocytes in migrating-nucleus stage are in ovarian lamellae, indicating that the ovary is about to spawn again. Fig. 2 E1.

Partial post-spawning. Post-ovulatory follicles are present, but it is difficult to identify them, because they are in advanced reabsorption grade. Oocytes in Vt1 and Vt2 stages are present. The Vt2 batch is in diapausa, without signs of follicular atresia or final maturation processes. Fig. 2 E2.

Post-spawning. Ovarian stroma has oocytes in all stages. Also there are remnants oocytes in follicular atresia. The ovarian stroma tissue is disorganized, not compact and in there are occurring reabsorption process. Fig. $2 \mathrm{~F}$.

Resting. The ovarian stroma appearance is almost compact and organized. The ovary wall and lamellae's connective tissue are thick with respect to ovary in immature phase. Only nuclear chromatin and perinucleolar oocytes are in ovarian lamellae. Fig. 2 G.

\section{Morphochromatic features}

The ovaries are small (IGS $=0.5 \pm 0.22$ ), turgent, and ligh orange or pinkish (RGB: 173, 63, 28). The vascularization is not evident. Fig. 2 A.

The ovaries are creamy orange color (RGB: 185, 104 89 ), turgent and bigger (IGS $=0.9 \pm 0.33$ ), with eviden vascularization. The oocytes cannot be observed with a naked eye. Fig. 2 B.

The ovaries are orange (RGB: 186, 109, 74), turgent anc bigger ( $\mathrm{IGS}=3.4 \pm 1.62$ ). The vascularization is more evident. The oocytes can be observed with a naked eye Fig. 2 C.

The ovaries are orange (RGB: 200, 114, 63) and turgent The edges of ovarian lobes are wavy and the ovariar wall looks tight to content. The vascularization anc ovarian size (IGS $3.2 \pm 0.71$ ) can be similar than in late developing phase. The oocytes can be observed with : naked eye. (Fig. 2 D).

The ovaries are light orange (RGB: $218,154,127)$ anc slightly flaccid. The vascularization looks more branchec and thinner than in p revious ovarian phases. The ovariar size can be similar than in la te developing and mature phases (IGS=3.1 \pm 1.2 ). The oocytes can be observec with a naked eye, in less density than in ovarian phases described previously. (Fig. 2 E). The partial spawning and partial post-spawning sub-phases present simila1 morphochromatic features.

The ovaries are flaccid, dark brown (RGB: 63, 12, 11, with orange tonality in some parts (RGB: 155, 81, 36. and smaller (IGS $=0.9 \pm 1.22$ ). The oocytes cannot be observed with a naked eye. Fig. 2 F.

The ovaries in resting phase present simila1 morphochromatic features than ovaries in i mmature phase. The ovaries are small (IGS $=0.5 \pm 0.22$ ), turgent anc light orange (RGB: 154, 51, 37) or pinkish (RGB: 205 122, 88). Fig. 2 G.

\section{DISCUSSION}

The form and position of gonads are related with body form of $P$. medius, as in other fishes (McMillan, 2007). $P$. medius's laterally-compressed body and its narrow and in- flexible visceral cavity propitiate the position of gonadal lobes (one down and one up) and define the wider shape of the upper lobe, and if the cavity is deformed, the organ takes 


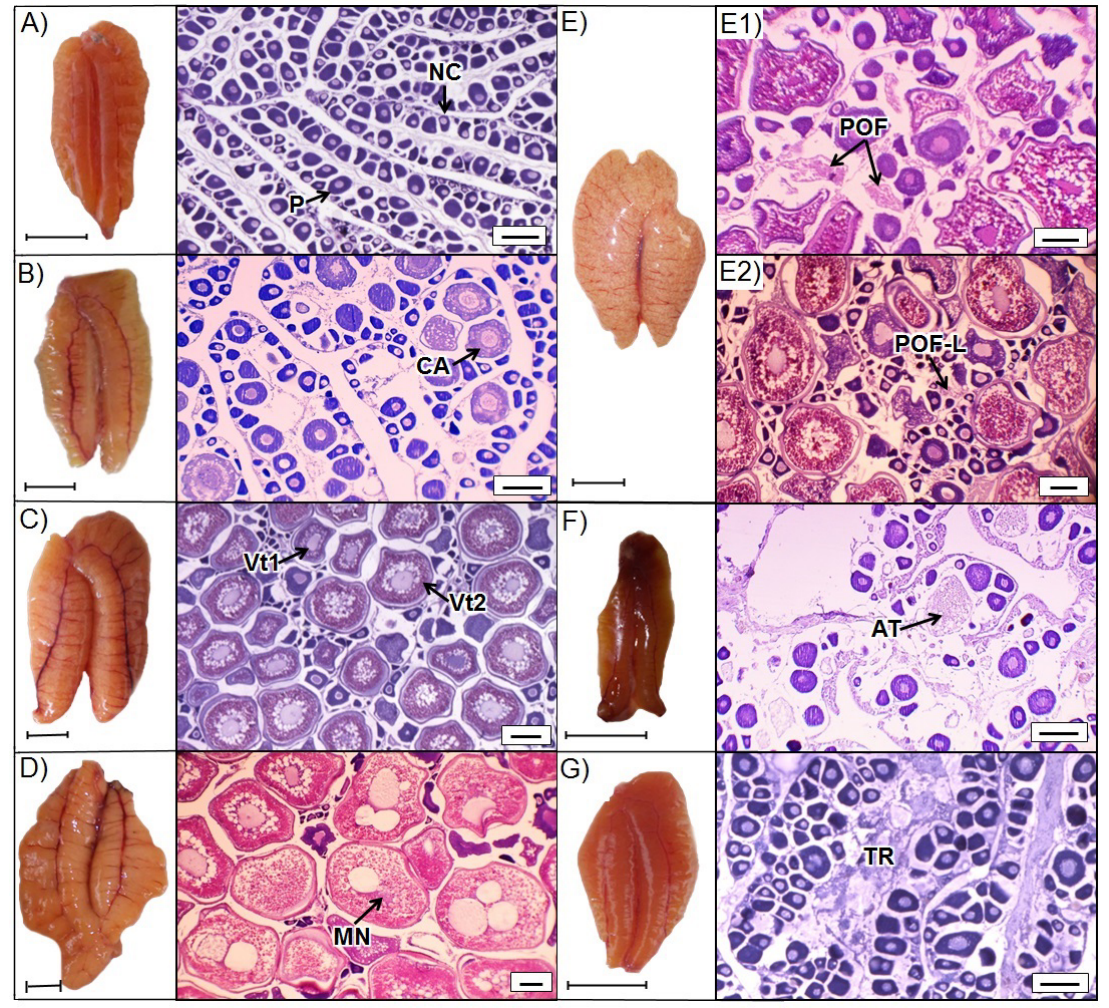

Fig. 2. Ovarian developmental phases and sub-phases of Peprilus medius: A, immature; $\mathrm{B}$, early developing (sub-phase); C, late developing (sub-phase); D, mature; E, spawning (E1, partial spawning sub-phase; E2, partial post-spawning sub-phase); G, post-spawning; $\mathrm{H}$, resting. Tissular and cellular structures in ovaries: NC, nuclear chromatin; $\mathrm{P}$, perinucleolar; CA, cortical alveolus; Vt1, early vitellogenesis; Vt2, late vitellogenesis; MN, migrating-nucleus; POF, Post-ovulatory follicle; POF-L, late post-ovulatory follicle; AT, atresia; TR, tissue in reabsorption. The bars's scale is $100 \mu \mathrm{m}(-)$ and $1 \mathrm{~cm}(\leftrightarrow)$. Hematoxylin-eosin technique.

the form. The gonads deformities can affect fishes fecundity (Wootton \& Smith, 2015), thus is very important that deformities do not occur in high proportion. The orientation of gonadal lobes from gonopore to posterior area of visceral cavity, is an adaptation that could be advantageous to minimize water pressure on gonads during swimming. This could permit that $P$. medius maintains displacement during spawning season taking care the gonads and let it spawn at different places.

$P$. medius's ovaries present asynchronous development, characterized by simultaneous presence of more than two oocyte stages during oogenesis according to Marza (1938). Females can spawn at least three times during spawning days period, evidencing that $P$. medius is batch partial spawner. This spawning pattern have been described for Pampus argenteus and Stromateus stellatus (Dadzie et al.; Almatar et al.; Lone et al.; Carocca \& Chong), also members of Stromateidae.

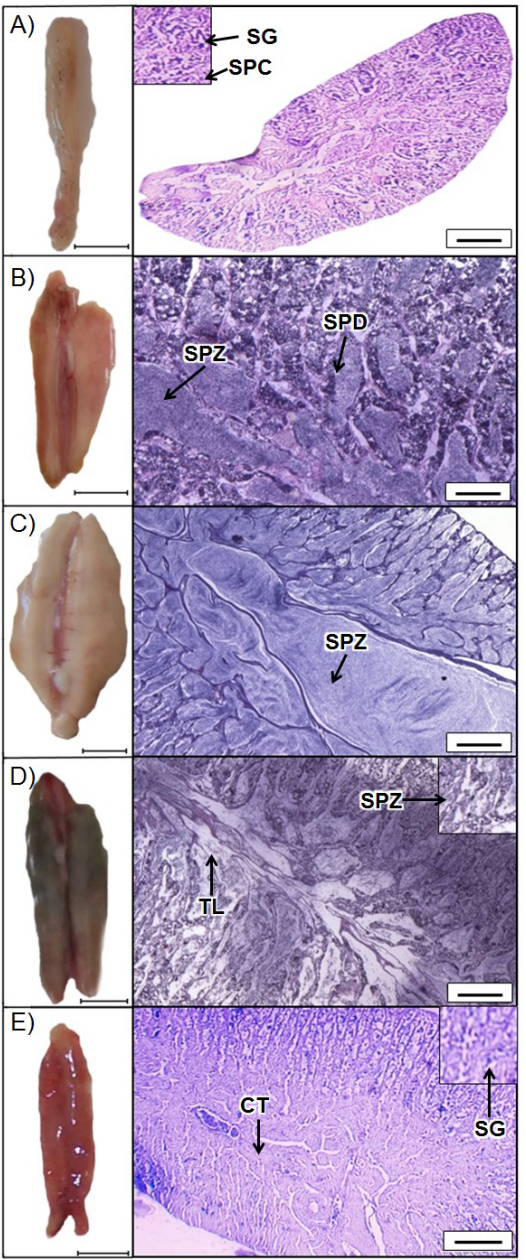

Fig. 3. Testicular developmental phases of Peprilus medius: A, immature; B, development; $\mathrm{C}$, ejaculation; $\mathrm{D}$, ejaculated; $\mathrm{E}$, resting. Tissular and cellular structures in testes: SG, spermatogonia; SPC, spermatocyte; SPD, spermatid; SPZ, spermatozoa; TL, spermatogenic tubule lumen; CT, connective tissue.

The external morphochromatic features of gonads are related with cellular and tissular changes in organs due to gametogenesis, similar to general gonadal development described to other fishes by authors like Lowerre-Barbieri et al. (2011), Brown-Peterson et al. (2011) and Wallace \& Selman. Thus, the gonadal development phases can be identified by morphochromatic features, except spawning's sub-phases and the difference between ovarian immature and resting phases, that can be only note by histological diagnosis. Therefore, the presented gonadal development scales gives possibility to define most developmental phases only with morphochromatic features, this being a desirable 
MALDONADO-AMPARO, M. A.; SÁNCHEZ-CÁRDENAS, R.; SALCIDO-GUEVARA, L.A. \& RAMÍREZ-PÉREZ, J. S. Gonadal development of Peprilus medius (Peters, 1869) (Perciformes: Stromateidae) from southeast of the Gulf of California, Mexico. Int. J. Morphol., 35(1):56-61, 2017.

Tabla II. Scale of testicular developmental phases of Peprilus medius from southeast of Gulf of California.

\begin{tabular}{|c|c|}
\hline Microscopic features & Morphochromatic features \\
\hline \multicolumn{2}{|l|}{ Phase } \\
\hline $\begin{array}{l}\text { Immature. The transversal appearance of testes' tissues is compact, and the } \\
\text { lumen of spermatogenic tubules are not formed. Spermatogonia and scarce } \\
\text { spermatocy tes are present in compacted tissue. Fig. } 3 \text { A. }\end{array}$ & $\begin{array}{l}\text { The testes are small (IGS }=0.03 \pm 0.03) \text {, thin } \\
\text { (thre adlike) and white (RGB: } 180,148,131) \text {. Fig. } \\
3 \mathrm{~A} \text {. }\end{array}$ \\
\hline $\begin{array}{l}\text { Development. The lumen of spermatogenic tubules are clearly defined. In } \\
\text { tubules' walls (germinal epithelium) are present active spermatogenic } \\
\text { activity (clusters of spermatocyte and spermatids). Spermatozoa are present } \\
\text { in the tubules' lumen, and increasing quantity according with the advance of } \\
\text { ripeness. Fig. } 3 \mathrm{~B} \text {. }\end{array}$ & $\begin{array}{l}\text { The testes are bigger (IGS }=0.94 \pm 0.97 \text { ), flattened, } \\
\text { turgent and pinkish (RGB: } 155,83,62) . \text { The } \\
\text { testicular lobes present the inner edge (between } \\
\text { both lobes) as a white stripe (RGB: 236, 222, 216). } \\
\text { Fig. } 3 \text { B. }\end{array}$ \\
\hline $\begin{array}{l}\text { Ejaculation. The walls of spermatogenic tubules are stretched. The lumen } \\
\text { of spermatogenic tubules and efferent ducts are full of spermatozoa. } \\
\text { Spermatozoa release is evidenced by the gradual emptying of spermatogenic } \\
\text { tubules and efferent duct. S permatocyte and spermatid proliferation persists } \\
\text { in the germinal epithelium, and decrease towards the end of spawning } \\
\text { season. Fig. } 3 \text { C. }\end{array}$ & $\begin{array}{l}\text { The testes are bigger (IGS }=1.17 \pm 0.89 \text { ), flaccid } \\
\text { and with tonalities between white and light brown } \\
\text { color (RGB: } 180,148,131 \text { ). The seminal fluid is } \\
\text { white (RGB: } 246,242,240 \text { ) and is easily issued at } \\
\text { the slightest pressure. Fig. } 3 \mathrm{C} \text {. }\end{array}$ \\
\hline $\begin{array}{l}\text { Ejaculated. The spermatogenic tubules are almost empty, with a f ew } \\
\text { reman ent spermatozoa. Also a few clusters of spermatocyte and spermatid } \\
\text { could be observed. The walls of spermatogenic tubules are stretched. Fig. } 3 \\
\text { D. }\end{array}$ & $\begin{array}{l}\text { The testes are smaller (IGS }=0.78 \pm 0.83 \text { ), flaccid } \\
\text { and black (RGB: } 65,60,54) \text { or pinkish in some } \\
\text { parts (RGB: } 115,62,54) \text {. Seminal fluid is not } \\
\text { issued, neither if pres sure is applied. Fig. } 3 \mathrm{D} \text {. }\end{array}$ \\
\hline $\begin{array}{l}\text { Resting. The connective tissue around spermatogenic tubules is thick, due } \\
\text { to shrinkage after stretch. Very few remanent spermatozoa could be } \\
\text { observed in efferent duct. The spermatogenic activity is not evident. Fig. } 3 \\
\text { E. }\end{array}$ & $\begin{array}{l}\text { The testes are smaller }(\mathrm{IGS}=0.19 \pm 0.2) \text { flaccid and } \\
\text { creamy pinkish (RGB: } 154,71,86) \text {. Fig. } 3 \mathrm{E} \text {. }\end{array}$ \\
\hline
\end{tabular}

attribute of scales because phases definition is quick and cheap (Lowerre-Barbieri et al.). This also makes it feasible to use the scales in extensive works, like fishery monitoring.

P. medius's gonadal developmental scales incorporate additional traits, for example, vascularization, turgor, IGS values and RGB color values, for easier phase definition. Other stromatids's scales do not include these features, as Pampus argenteus's scale (Lone et al.).

\section{ACKNOWLEDGEMENTS}

The authors thank the support from projects: PROFAPI-2014/165, PROFAPI-2014/199, 231525-Infraestructura-CONACYT-2014 and 2137-Cátedras CONACYT. Maldonado-Amparo is grateful the support from CONACyT fellowship programme (scholarship 634525). Sánchez-Cárdenas thanks the support from Cátedras CONACyT programme. Also we thank to anonymous reviewers, because their suggestions to this manuscript and to Mel Rudeen for English language revision.
MALDONADO-AMPARO, M. A.; SÁNCHEZ-CÁRDENAS, R.; SALCIDO-GUEVARA, L.A. \& RAMÍREZ-PÉREZ, J. S. Desarrollo gonádico de Peprilus medius (Peters, 1869) (Perciformes: Stromateidae) del sureste del Golfo de California, México. Int. J. Morphol., 35(1):56-61, 2017.

RESUMEN: La evaluación del desarrollo gonádico es una labor fundamental para investigar la reproducción de Peprilus medius, en vías a comprender la dinámica de sus poblaciones y lograr un manejo sustentable de sus pesquerías. El diagnóstico a partir de características morfocromáticas es el método más rápido, práctico y barato, y adecuadamente validado puede ser un procedimiento preciso. Este es particularmente útil en investigaciones cuando se requiere aportar información rápida y precisa que apoye la toma de decisiones de manejo pesquero, y durante los monitoreos pesqueros de largo plazo, que permiten detectar cambios en los patrones reproductivos debido a anomalías ambientales. Estos son temas preocupantes en $P$. medius y otros recursos pesqueros. En ese contexto se presenta una escala que describe el desarrollo gonádico a través de características morfocromáticas e histológicas, y además se presentan observaciones anatómicas de los órganos reproductores. El desarrollo ovárico fue caracterizado a través de seis fases: inmadura, desarrollo (subfases: inicial y avanzado), maduro, desove (subfases: parcial y postdesove parcial), postdesove 
y reposo. El desarrollo testicular fue descrito a través de cinco fases: inmadura, desarrollo, eyaculación y reposo. La posición y forma de los órganos reproductores están aparentemente definidos por la forma del pez y su cavidad visceral. Las gónadas de $P$. medius muestran un lóbulo gonádico en posición inferior y uno superior en la cavidad visceral, y ambos lóbulos presentan una colocación horizontal desde el gonoporo hacia la parte posterior del pez. Además se evidencia la ocurrencia de deformidades en las gónadas debido a deformidades en la cavidad visceral. Recomendamos utilizar las descripciones presentadas como una guía en la evaluación de las gónadas.

PAlabras Clave: Ovarios; Testículos; Gametogénesis; Anatomía reproductiva.

\section{REFERENCES}

Almatar, S. M.; Lone, K. P.; Abu-Rezq, T. S. \& Yousef, A. A. Spawning frequency, fecundity, egg weight and spawning type of silver pomfret, Pampus argenteus (Euphrasen) (Stromateidae), in Kuwait waters. $J$. Appl. Ichthyol., 20(3):176-88, 2004.

Brown-Peterson, N. J.; Wyanski, D. M.; Saborio-Rey, F.; Macewicz, B. J. \& Lowerre-Barbieri, S. K. A Standardized Terminology for Describing Reproductive Development in Fishes. Mar. Coast. Fish. Dyn. Manag. Ecosyst. Sci., 3(1):52-70, 2011.

Buesa, R. J. \& Peshkov, M. V. Histology without xylene. Ann. Diagn. Pathol., 13(4):246-56, 2009.

Chirichigno, N. \& Velez, M. Clave para Identificar los Peces Marinos del Perú. Lima, Instituto del Mar del Perú, 1998.

Carocca, C. \& Chong, J. Actividad ovárica del pampanito, Stromateus stellatus en el litoral de la Región del Biobío, Chile. Rev. Biol. Mar. Oceanogr., 45 Supl. 1:751-5, 2010.

Dadzie, S.; Abou-Seedo, F. \& Al-Shallal, T. Reproductive biology of the silver pomfret, Pampus argenteus (Euphrasen), in Kuwait waters. $J$. Appl. Ichthyol., 16(6):247-53, 2000.

Devlaming, V.; Grossman, G. D. \& Chapman, F. On the use of the gonadosomatic index. Comp. Biochem. Physiol. Part A Physiol., 73(1):31-9, 1982.

Humason, G. L. Animal Tissue Techniques. $4^{\text {th }}$ ed. San Francisco, W. H. Freeman Co., 1979.

Inga-Barreto, C.; Rujel-Mena, J.; Ordinola-Zapata, E. \& Gómez-Sulca, E. El chiri, Peprilus medius (Peters) en Tumbes, Perú. Parámetros biológico-pesqueros y talla mínima de captura. Inst. Mar Perú, 35(3):20914, 2008.

Kameya, A.; Lleellish, M. \& Caccha, L. Los Peces como Indicadores de El Niño en el Ecosistema Marino Peruano desde 1972 a 1998. In: Tarazona, J.; Arntz, W. \& Castillo, E. (Ed.). El Niño en América Latina. Impactos Biológicos y Sociales. Lima, Omega, 2001. pp.81-9.

King, J. R. \& McFarlane, G. A. Marine fish life history strategies: applications to fishery management. Fish. Manag. Ecol., 10(4):24964, 2003.

Kobelkowsky, A. Morphological diversity of the ovaries of the mexican teleost fishes. Int. J. Morphol., 30(4):1353-62, 2012.

Lone, K. P.; Al-Ablani, S. \& Almatar, S. Oogenesis, histological gonadal cycle, seasonal variations and spawning season of female silver pomfret (Pampus argenteus, Euphrasen) from the spawning grounds of Kuwait. Pak. J. Zool., 40(6):397-407, 2008.

Lowerre-Barbieri, S. K.; Brown-Peterson, N. J.; Murua, H.; Tomkiewicz, J.; Wyanski, D. M. \& Saborido-Rey, F. Emerging issues and methodological advances in fisheries reproductive biology. Mar. Coast. Fish. Dyn. Manag. Ecosyst. Sci., 3:32-51, 2011.
Marza, V. D. Histophysiologie de I'ovogen'ese. Paris,Hermann, 1938.

McMillan, D. B. Fish Histology. Female Reproductive Systems. Toronto, Springer, 2007.

Murphy, M. D. \& Chittenden Jr., M. E. Reproduction, age and growth, and movements of the gulf butterfish Peprilus burti. Fish. Bull., (89)1:10116, 1991.

Núñez, J. \& Duponchelle, F. Towards a universal scale to assess sexual maturation and related life history traits in oviparous teleost fishes. Fish. Physiol. Biochem., 35(1):167-80, 2009.

Palacios-Salgado, D.S.; Moreno-Sánchez, X.G.; Abitia-Cárdenas, L.A.; Gutierrez-Sánchez, F.J. \& Rodríguez-Romero, J. Ichtyodiversiry of San Jose, San Francisco, and El Pardito Islands in the southwestern Gulf of California, México. Acta. Ichthyol. Piscat., 42:177-91, 2012.

Prado, M. La pesquería de peces pelágicos pequeños en Ecuador durante 2008. Bol. Cient. Técn. Inst. Nac. Pesca Ecuad., 20(4):1-25, 2010.

Tam, J.; Taylor, M. H.; Blaskovic, V.; Espinoza, P.; Michael Ballón, R.; Díaz, E.; Wosnitza-Mendo, C.; Argüelles, J.; Purca, S.; Ayón, P.; Quipuzcoa, L.; Gutiérrez, D.; Goya, E.; Ochoa, N. \& Wolff, M. Trophic modeling of the Northern Humboldt Current Ecosystem, Part I: Comparing trophic linkages under La Niña and El Niño conditions. Prog. Oceanogr., 79(2):352-65, 2008.

Tobón-López, A.; Rubio, E. A. \& Gildardo, A. Composición y análisis taxonómico de la íctiofauna del golfo de Tribugá, Pacífico norte de Colombia. Lat. Am. J. Aquat. Res., 36(1):93-104, 2008.

Wallace, R. A. \& Selman, K. Cellular and dynamic aspects of oocyte growth in teleost. Am. Zool., 21(1):325-43, 1981.

Wootton, R. J. \& Smith, C. Reproductive Biology of Teleost Fishes. Hoboken, Wiley Blackwell, 2015.

\section{Corresponding author: Rebeca Sánchez-Cárdenas CONACYT - FACIMAR, UAS MEXICO}

\section{Email: rsanchez@uas.edu.mx}

Received: 17-10-2016

Accepted: 23-12-2016 